Published in final edited form as:

Pharmacol Ther. 2017 October ; 178: 48-56. doi:10.1016/j.pharmthera.2017.03.009.

\title{
Imidazoline $\mathrm{I}_{2}$ receptors: an update
}

\author{
Jun-Xu Li ${ }^{1,2}$ \\ ${ }^{1}$ School of Pharmacy, Nantong University, Nantong, Jiangsu Province, China \\ 2Department of Pharmacology and Toxicology, Jacobs School of Medicine and Biomedical \\ Sciences, University at Buffalo, Buffalo, New York, USA
}

\begin{abstract}
Since first introduced more than two decades ago, the research in imidazoline $\mathrm{I}_{2}$ receptors has been steadily increasing. This review provides an update on the current status of $I_{2}$ receptor pharmacology. Imidazoline $\mathrm{I}_{2}$ receptors or $\mathrm{I}_{2}$ binding sites refer to several (at least four) different proteins that bind to $\left[{ }^{3} \mathrm{H}\right]$-idazoxan and $\left[{ }^{3} \mathrm{H}\right]$-2-BFI with high affinity. The molecular identities of the proteins remain elusive. One of the proteins $(45 \mathrm{kD})$ seems to be consistent with the identity of brain creatine kinase. The biological functions of $\mathrm{I}_{2}$ receptors have been primarily unveiled by the studies of selective $\mathrm{I}_{2}$ receptor ligands. Accumulating evidence suggests that $\mathrm{I}_{2}$ receptor ligands are effective analgesics for persistent and chronic painful conditions such as inflammatory, neuropathic and postoperative pain. One selective $\mathrm{I}_{2}$ receptor ligand, CR4056, has been advanced to phase II clinical trial with the therapeutic indication of chronic inflammatory pain (osteoarthritis). The expansion to the treatment of other chronic pain conditions should be expected if CR4056 could eventually be approved as a new drug. $\mathrm{I}_{2}$ receptor ligands also demonstrate robust discriminative stimulus activity and induce a characteristic discriminative cue in animals. Biochemical and preclinical in vivo investigations also suggest that $\mathrm{I}_{2}$ receptor ligands have neuroprotective activity and modulate body temperature. The emerging discrepancies of a range of purported selective $\mathrm{I}_{2}$ receptor ligands suggest different pharmacological effects mediated by discrete $I_{2}$ receptor components which likely attribute to the $I_{2}$ receptor-related proteins. It is proposed that the $I_{2}$ receptors represent an emerging drug target for the treatment of neurological disorders such as pain and stroke, and deserve more research attention to translate preclinical findings to pharmacotherapies.
\end{abstract}

\section{Keywords}

Imidazoline $\mathrm{I}_{2}$ receptor; pain; drug discrimination; neuroprotection; body temperature

Corresponding author: Jun-Xu Li, MD, Ph.D, Department of Pharmacology and Toxicology, Jacobs School of Medicine and Biomedical Sciences, The State University of New York at Buffalo, Buffalo, New York, USA 14214, Tel: (01) 716-829 2482, junxuli@buffalo.edu.

Publisher's Disclaimer: This is a PDF file of an unedited manuscript that has been accepted for publication. As a service to our customers we are providing this early version of the manuscript. The manuscript will undergo copyediting, typesetting, and review of the resulting proof before it is published in its final citable form. Please note that during the production process errors may be discovered which could affect the content, and all legal disclaimers that apply to the journal pertain.

Conflict of Interest

The author declares no conflict of interest. 


\section{Introduction}

Many biologists are likely unfamiliar with the concept imidazoline receptors, even those who study drugs as a career, viz. pharmacologists. This is not surprising. In the 12th edition of Goodman \& Gilman's The Pharmacological Basis of Therapeutics (Brunton, Chabner, \& Knollman, 2011), commonly referred to as the Blue Bible of pharmacology, there is only one sentence mentioning imidazoline receptors. In the $5^{\text {th }}$ edition of the Guide to Receptors and Channels (Alexander, Mathie, \& Peters, 2011), an authoritative book compiling the major pharmacological targets, imidazoline receptors are only briefly mentioned using one sentence under the entry of adrenergic $a_{2}$ receptors. This indicates that the concept of imidazoline receptor has not received unanimous acceptance in the biomedical community. This is primarily driven by two reasons: 1) the nature of imidazoline receptors and their respective signaling pathways have not been characterized;2) there is currently no clinically-used drug that was developed based on imidazoline receptor pharmacology, although there are known therapeutic drugs that may act on imidazoline receptors. For example, moxonidine and rilmenidine are thought to act on imidazoline $\mathrm{I}_{1}$ receptors (Head \& Mayorov, 2006). However, this field has been a small but robust scientific field for more than 3 decades. Since 1992, five international symposia with a focus on imidazoline receptors have been held, along with three monographs and two special issues on field scientific journals (Table 1). In addition, a PubMed search shows that publications with terms of "imidazoline receptors OR imidazoline binding sites" grew steadily since early 1980s, reaching nearly 2300 hits (left, Figure 1). These publications include a large body of literature regarding agmatine and many others that do not differentiate imidazoline receptor subtypes. A more refined search using terms of "imidazoline $\mathrm{I}_{1}$ receptors OR imidazoline $\mathrm{I}_{1}$ binding sites $O R \mathrm{I}_{1}$-imidazoline" and "imidazoline $\mathrm{I}_{2}$ receptors $\mathrm{OR}$ imidazoline $\mathrm{I}_{2}$ binding sites OR $\mathrm{I}_{2}$-imidazoline" reached more than 450 and 270 hits, respectively, which again showed a steady growth over the years (right, Figure 1). Decades of research has built a significant body of knowledge on imidazoline receptors.

Earlier research in the field of imidazoline receptors has been extensively reviewed elsewhere (Eglen et al., 1998; Head \& Mayorov, 2006; Michel \& Ernsberger, 1992; Parini, Moudanos, Pizzinat, \& Lanier, 1996; Regunathan \& Reis, 1996). Interested readers are encouraged to refer to those reviews on this topic and the related information will not be reiterated here. In essence, much attention of previous research had been focusing on imidazoline $\mathrm{I}_{1}$ receptors and potential clinical implications such as hypertension (Head \& Mayorov, 2006). However, the understanding of imidazoline $I_{2}$ receptors and its potential functionality had always been elusive until recently. The purpose of this piece is to review the current status of imidazoline $\mathrm{I}_{2}$ receptors and related receptor ligands, which has seen an emerging research interest in recent years, and to provide a perspective in future directions of this field.

\section{What is imidazoline $I_{2}$ receptors?}

Imidazoline receptors originally refer to the binding sites that are recognized by radiolabelled adrenergic ligands such as $\left[{ }^{3} \mathrm{H}\right]$ clonidine, $\left[{ }^{3} \mathrm{H}\right] \mathrm{p}$-aminoclonidine and $\left[{ }^{3} \mathrm{H}\right]$ idazoxan (also known as RX781094) that are insensitive to norepinephrine and are not adrenergic 
receptors (Coupry, Podevin, Dausse, \& Parini, 1987; Ernsberger, Meeley, Mann, \& Reis, 1987). These non-adrenergic clonidine binding sites account for $\sim 30 \%$ of the total binding and are grossly termed imidazoline receptors. Later research discovered that for these nonadrenergic binding sites, there were at least two different populations which were sensitive to ligands such as $p$-aminoclonidine and moxonidine or idazoxan and cirazoline, respectively. They were then termed imidazoline $\mathrm{I}_{1}$ and $\mathrm{I}_{2}$ receptors, respectively (Regunathan \& Reis, 1996). Therefore, for the purpose of this review, imidazoline $\mathrm{I}_{2}$ receptors refere to the non-adrenergic binding sites that bind to $\left[{ }^{3} \mathrm{H}\right]$-idazoxan with high affinity and $\left[{ }^{3} \mathrm{H}\right]$-p-aminoclonidine and $\left[{ }^{3} \mathrm{H}\right]$-clonidine at substantially lower affinity (Regunathan \& Reis, 1996).

From the early beginning, it was realized that the imidazoline $\mathrm{I}_{2}$ receptors are highly heterogenous. Largely through binding studies, it was initially proposed to differentiate $\mathrm{I}_{2}$ receptors into two different subtypes based on their binding affinity to the drug amiloride: $I_{2 A}$ and $I_{2 B}$ subtypes (Diamant, Eldar-Geva, \& Atlas, 1992). After all, most drug competition curve studies of binding to $I_{2}$ receptors revealed biphasic curves depending on which drug was used as a competitor (Miralles et al., 1993). However, functional evidence supporting such a proposition had been lacking. A biochemical investigation using a polyclonal antiserum againist imidazoline receptor proteins revealed four different protein bands and the bands were not identical between rat and rabbit brain tissues (rat brains: $\sim 30$, $\sim 45, \sim 66, \sim 85 \mathrm{kD}$; rabbit brains: 30, 57, 66, $85 \mathrm{kD}$ ) (Olmos, Alemany, Boronat, \& Garcia-Sevilla, 1999). In addition, chronic treatment with selective $\mathrm{I}_{2}$ receptor ligands such as BU224 and tracizoline (also known as LSL61122, valldemossine) significantly reduced while treatment with idazoxan increased the $30 \mathrm{kD}, 45 \mathrm{kD}$ and $66 \mathrm{kD}$ protein levels in the mouse brain (Keller \& Garcia-Sevilla, 2015), indicating the biochemcial relevance of $\mathrm{I}_{2}$ receptor ligands and these proteins. Using a selective and high affinity $\mathrm{I}_{2}$ receptor ligand 2BFI to generate affinity column, a protein was successfully isolated and sequenced which was identified as the brain creatine kinase (Kimura et al., 2009). This protein may account for the $\sim 45 \mathrm{kD}$ protein band reported earlier (Olmos, Alemany, et al., 1999). However, the identities of other protein bands remain unknown and it is still unclear whether and how much the reported pharmacological effects of various $\mathrm{I}_{2}$ receptor ligands could be attributable to and explained by their activities on brain creatine kinase.

Cellular distribution studies revealed that $I_{2}$ receptors are primarily located on the outer membrane of mitochondria and may be novel allosteric binding sites of monoamine oxidases (MAO) A and B (Tesson et al., 1995; Tesson, Prip-Buus, Lemoine, Pegorier, \& Parini, 1991). However, MAO cannot account for all the $I_{2}$ receptor binding and non-MAO $I_{2}$ binding sites were also found in MAO knockout mice (Anderson, Seif, Nutt, Hudson, \& Robinson, 2006; Remaury et al., 2000). For example, brain creatine kinase is unrelated to MAO, as described above (Kimura et al., 2009).

In summary, there remains a lack of consensus regarding the nature of $I_{2}$ receptors. It seems clear that $\mathrm{I}_{2}$ receptors may represent a group of heterogenous proteins that $\mathrm{I}_{2}$ receptor ligands such as idazoxan and 2-BFI recognize, some of which are related to MAO and others are not. Therefore, it is important to note that when referring to $I_{2}$ receptors in the literature, it does not refer to a speicified molecular identity; rather, it refers to several different and 
potentially biologically diverse protein molecules. This definition is criticial in helping to interpret functional results that have been quickly emerging in recent years. As will be detailed later, given the fact that the understanding of molecular identifies of $\mathrm{I}_{2}$ receptors has seen limited progress in the past two decades, now it may be time to take an alterative approach to characterize $\mathrm{I}_{2}$ receptors and advance $\mathrm{I}_{2}$ receptor-based pharmacotherapies.

\section{Endogenous and synthetic imidazoline $I_{2}$ receptor ligands}

The pursuit of endogenous ligands began soon after the concept of imidazoline receptor was introduced. An important cornerstone in the field was the report that agmatine may be the endogenous ligand of imidazoline receptor system (G. Li et al., 1994). It was soon proposed that agmatine is an endogenous neuromodulator (Reis \& Regunathan, 2000). Agmatine is a metabolic intermediate in polyamine biosynthesis and is widely seen in plants, bacteria, and invertebrates (Tabor \& Tabor, 1984). At pharmacological doses, agmatine produces various biological effects, some of which are therapeutically relevant (Piletz et al., 2013). However, agmatine only has moderate to low affinity at adrenergic receptors and imidazoline receptors (Reis \& Regunathan, 2000). Few studies demonstrate a direct modulatory action of agmatine on imidazoline receptors. Therefore, although currently agmatine is usually presumed as the endogenous ligand of imidazoline receptor system, its role in directly modulating (activating) imidazoline receptors remains elusive.

Because idazoxan was initially used to characterize $\mathrm{I}_{2}$ receptors and it also binds to adrenoceptors, medicinal chemistry efforts have been actively developing selective $\mathrm{I}_{2}$ receptor ligands. A partial list of the reported $\mathrm{I}_{2}$ receptor ligands was previously discussed (J. X. Li \& Zhang, 2011). Several other synthetic $\mathrm{I}_{2}$ receptor ligands are described more recently in a preliminary manner and are not included, including a recent study that described a new family of (2-imidazolin-4-yl) phosphonates that had high affinity to $\mathrm{I}_{2}$ receptors (Abas et al., 2017). Among these, several compounds have been frequently used in the literature to explore the pharmacological effects related to $I_{2}$ receptors and becoming invaluable research tools, such as 2-BFI, BU224, phenyzoline and CR4056. More importantly, CR4056 has advanced to phase II clinical trials for the treatment of chronic pain. If approved, CR4056 would be the first $\mathrm{I}_{2}$ receptor mechanism-based pharmacotherapy, which naturally would become one of the most important milestones in imidazoline receptor research.

\section{Neuropharmacology of imidazoline $I_{2}$ receptor ligands}

Despite the fact that the molecular nature of $\mathrm{I}_{2}$ receptors remains elusive, selective $\mathrm{I}_{2}$ receptor ligands as identified by receptor binding assays have provided critical tools and the study of these compounds have offered insights into the understanding of the roles $\mathrm{I}_{2}$ receptors play in mediating some pharmacological effects. In the past several years, numerous studies have been published that described various central nervous system (CNS)mediated pharmacological effects produced by the $\mathrm{I}_{2}$ receptor ligands. One presumption underlying all these studies was that certain pharmacological effects induced by a specific $\mathrm{I}_{2}$ receptor ligand are truly mediated by $\mathrm{I}_{2}$ receptors as long as the ligand selectively binds to $\mathrm{I}_{2}$ receptors and the effects are blocked by idazoxan, the only known functional $\mathrm{I}_{2}$ receptor 
antagonist (but see 4.2 Discriminative stimulus effects). It should be noted that because knocking out $\mathrm{I}_{2}$ receptors is impossible, the pharmacological specificity of these effects could not be crosschecked using relevant knockout animals. One way that can indirectly address this issue is to use an irreversible receptor antagonist to inactivate the receptors. BU99006 is reported to be an irreversible $\mathrm{I}_{2}$ receptor ligand that can reduce the available $\mathrm{I}_{2}$ receptors (Tyacke et al., 2002). However, behavioral studies show that BU99006 functions as an $\mathrm{I}_{2}$ receptor agonist (Qiu et al., 2014b). Nevertheless, the exciting new findings as seen recently have already greatly improved our understanding of imidazoline $\mathrm{I}_{2}$ receptor pharmacology.

\subsection{Pain}

In 2011, we published a review paper proposing that $\mathrm{I}_{2}$ receptors may be a novel drug target for the development of analgesics (J. X. Li \& Zhang, 2011). However, there were relatively little evidence that $\mathrm{I}_{2}$ receptors mediate analgesia and most cited studies in that review used agmatine, a compound that only has moderate affinity at $\mathrm{I}_{2}$ receptors. Nevertheless, the existing literature reporting antinociceptive effects of agmatine and synthetic $\mathrm{I}_{2}$ receptor ligands generally suggests that agmatine is effective in many animal models of persistent and chronic pain but has little effect in models of acute nociception (J. X. Li \& Zhang, 2011). Since then, many studies using more selective $I_{2}$ receptor ligands have been published supporting this notion.

Several studies have shown that selective $\mathrm{I}_{2}$ receptor ligands have no antinociceptive effect in rodent models of acute nociception. For example, several $\mathrm{I}_{2}$ receptor ligands including 2BFI, tracizoline, phenyzoline and LSL60101 do not produce significant antinociception in rodent radiant tail flick and hot plate assays (Boronat, Olmos, \& Garcia-Sevilla, 1998; Gentili et al., 2006; Sanchez-Blazquez, Boronat, Olmos, Garcia-Sevilla, \& Garzon, 2000). We also found that in a rat warm water tail withdrawal assay, selective $\mathrm{I}_{2}$ receptor ligands such as 2-BFI and phenyzoline only produced mild antinociceptive effect while other selective $\mathrm{I}_{2}$ receptor ligands such as BU224 and S22687 did not have antinociceptive effect when the thermal stimulus was weak $\left(46{ }^{\circ} \mathrm{C}\right.$ water) and all the $\mathrm{I}_{2}$ receptor ligands failed to produce significant effect when the stimulus was increased to $50{ }^{\circ} \mathrm{C}$ (Sampson, Zhang, Del Bello, \& Li, 2012; Thorn, Zhang, Peng, Winter, \& Li, 2011). Overall, these results consistently show that $\mathrm{I}_{2}$ receptor ligands do not alter acute nociception.

Three studies examined the antinociceptive effects of $\mathrm{I}_{2}$ receptor ligands in chemical stimulation-induced pain models. In a rat model of hypertonic saline-induced writhing test, 2-BFI, BU224 and morphine were equally effective in decreasing the writhing response (J. X. Li, Zhang, \& Winter, 2011). Importantly, the antinociceptive effects were antagonized by idazoxan, suggesting that the effect was mediated by $\mathrm{I}_{2}$ receptors. CR4056 is a structurally novel $\mathrm{I}_{2}$ receptor agonist (Ferrari et al., 2011). Intraplantar injection of capsaicin induces robust mechanical hyperalgesia and CR4056 potently and fully reversed capsaicin-induced neurogenic/inflammatory hyperalgesia, an effect that was dose-dependently reversed by idazoxan (Ferrari et al., 2011). Formalin test is a widely-used chemical stimulation-induced persistent pain model, which typically demonstrates two phases: an early phase I which is primarily neurogenic and a later phase II which is primarily inflammatory (Hunskaar \& 
Hole, 1987). In a study using formalin test, 2-BFI, BU224 and the novel $\mathrm{I}_{2}$ receptor ligand CR4056 all dose-dependently reduced the flinching response during phase II, but only 2-BFI and BU224 were effective in phase I (Thorn, Qiu, Jia, Zhang, \& Li, 2016). Interestingly, idazoxan was only partially effective in attenuating the effects of 2-BFI and BU224 in phase I while no significant blockade was seen in phase II (Thorn, Qiu, et al., 2016). Although the mechanism why idazoxan failed to attenuate the $\mathrm{I}_{2}$ receptor ligands-induced antinociception in phase II remains unknown, one plausible explanation is that $\mathrm{I}_{2}$ receptor ligands produce the antinociceptive effect by acting on one of the components of $I_{2}$ receptors which is insensitive to idazoxan (Thorn, Qiu, et al., 2016).

Several studies have shown that $\mathrm{I}_{2}$ receptor ligands are effective in various animal models of chronic pain. In a complete Freund's adjuvant (CFA)-induced inflammatory pain model, three selective $\mathrm{I}_{2}$ receptor ligands (2-BFI, BU224 and tracizoline) all dose-dependently and significantly reduced the mechanical and thermal hyperalgesia (Li, Thorn, Qiu, Peng, \& Zhang, 2014). 2-BFI and the $\mathrm{I}_{2}$ receptor ligand phenyzoline also reduced mechanical hyperalgesia in rats that received chronic constriction injury (CCI), a model of peripheral neuropathic pain ( $\mathrm{Li}$ et al., 2014; Thorn, Zhang, \& Li, 2017). The anti-hyperalgesic effect of 2-BFI was attenuated by idazoxan, confirming $\mathrm{I}_{2}$ receptor mediated mechanism ( $\mathrm{Li}$ et al., 2014). Similar effects were also reported with phenyzoline in CFA-treated rats (Siemian, Li, Zhang, \& Li, 2016a; Thorn, Siemian, Zhang, \& Li, 2015). CR4056 also showed marked anti-hyperalgesic efficacy in several different rat models of chronic pain. CR4056 reduced mechanical hyperalgesia in CFA-treated rats (Ferrari et al., 2011), attenuated the mechanical hyperalgesia in diabetes-induced neuropathic pain (Ferrari et al., 2011), and reduced chronic chemotherapeutic agent bortezomib treatment-induced neuropathic pain (Meregalli et al., 2012). Although no antagonist combination study was performed in these three painful conditions, given the receptor specificity of CR4056 in the panel of receptor binding assay and other studies that employed idazoxan as the $I_{2}$ receptor antagonist (Ferrari et al., 2011), it seems reasonable to assume the $\mathrm{I}_{2}$ receptor-mediated mechanism underlying the antinociceptive actions of CR4056. In addition, CR4056 also showed antinociceptive efficacy in a rat model of fibromyalgia (Ferrari et al., 2011). Acidic saline $(\mathrm{pH}=4,150 \mu \mathrm{L})$ injected into the right gastrocnemius muscle can lead to a chronic mechanical hyperalgesia condition, a process that is believed to be centrally mediated. This model is thought to mimic human chronic pain syndromes such as fibromyalgia (Nielsen, Mathiesen, \& Blackburn-Munro, 2004). CR4056 significantly reversed acidic saline-induced mechanical hyperalgesia (Ferrari et al., 2011), suggesting the possibility that CR4056 may be efficacious against certain form of fibromyalgia. In another study, a postoperative pain model was used to assess the potential anti-hyperalgesia effect of CR4056 (Lanza, Ferrari, Menghetti, Tremolada, \& Caselli, 2014). In this study, postsurgical mechanical hyperalgesia was established and CR4056 dose-dependently and fully reversed the mechanical hyperalgesia, an effect that was fully blocked by idazoxan, but not by the opioid antagonist naloxone or the imidazoline $\mathrm{I}_{1}$ receptor antagonist efaroxan (Lanza et al., 2014). It is important to note that the same study also used female rats to examine the potential sex difference for CR4056-induced antinociception and no sex difference was found (Lanza et al., 2014). Together, these series of studies convincingly show that imidazoline $\mathrm{I}_{2}$ receptor agonists are able to attenuate various chronic painful conditions. This is significant because many 
chronic pain conditions are not responsive to existing pharmacotherapies and the above findings support the notion that $\mathrm{I}_{2}$ receptor ligands could be a novel class of analgesics for the treatment of complex chronic pain conditions. Indeed, CR4056 has successfully finished a Phase I clinical trial and is currently under Phase II trial for the treatment of chronic inflammatory pain conditions (EudraCT Number: 2015-001136-37). If successful, this would be the first-in-class drug to treatment chronic pain based on $\mathrm{I}_{2}$ receptor pharmacology and an analgesic with completely novel mechanism of action.

Through the above analysis of existing literature, it should be clear that $\mathrm{I}_{2}$ receptor ligands are most effective for the management of chronic pain and persistent pain, but are ineffective for acute pain. Because chronic pain typically is long-lasting and pharmacotherapy of chronic pain requires repeated drug use, it is important to understand the potential consequences of prolonged drug treatment in preclinical studies. Three studies attempted to address this concern. In one study, daily treatment with 2-BFI or CR4056 at the dose that produced the maximal anti-hyperalgesic effect for at least one week failed to produce observable antinociceptive tolerance in CFA-treated rats (Li et al., 2014). In another study that employed chemotherapeutic agent-induced neuropathic pain model, daily oral dosing with a CR4056 dose $(6 \mathrm{mg} / \mathrm{kg})$ that nearly fully prevented mechanical hyperalgesia for 3 weeks did not demonstrate observable antinociceptive tolerance (Meregalli et al., 2012). However, doses higher than $20 \mathrm{mg} / \mathrm{kg}$ did develop antinociceptive tolerance after two weeks, a process that was substantially slower than that during buprenorphine treatment (Meregalli et al., 2012). We recently found that twice-daily treatment with phenyzoline at the dose that produced near maximal antinociceptive effect in the CFA and CCI rat chronic pain models for 19 days only produced a slight although significant antinociceptive tolerance (Thorn, Zhang, \& Li, 2017). As a comparison, oxycodone produced dramatic tolerance to its antinociceptive effect under similar treatment conditions (Thorn, Zhang, \& Li, 2017). Combined, the results suggest that the process of tolerance development is slow, if at all, as long as the dose used is limited to therapeutically relevant dose.

Given the complex etiology of various chronic painful conditions, monotherapy with single analgesics may not achieve the optimal clinical pain management. Combination therapy is a viable strategy which combines two or more medications for pain control. This strategy may be able to achieve better analgesia and produce less adverse effects due to the smaller doses used or counteractive interaction of the drug combination in producing certain adverse effects. Several studies have examined the antinociceptive interactions between imidazoline $\mathrm{I}_{2}$ receptor ligands and other analgesic agents. Although 2-BFI alone had no significant antinociceptive effect in the tail withdrawal assay, it markedly enhanced the effects of morphine and tramadol when administered as a pretreatment drug, shifting the opioid antinociceptive dose-effect curve leftward (Thorn et al., 2011). Thus, it may be possible to use the $\mathrm{I}_{2}$ receptor ligand-opioid combination therapy to treat acute pain by substantially reducing the required opioid dose, which can be clinically significant. In the hypertonic saline-induced writhing test, the combination of morphine and 2-BFI or BU224 produced synergistic antinociception (J. X. Li et al., 2011). However, both morphine and oxycodone produced additive antinociceptive interaction with 2-BFI in CFA-treated rats (Li et al., 2014; Thorn et al., 2015). The interaction between 2-BFI and opioids is partially determined by the efficacy of opioids on $\mu$-opioid receptors because lower efficacy opioids such as 
buprenorphine and NAQ produced synergistic interactions while high efficacy opioids such as fentanyl produced additive interactions with 2-BFI (Siemian, Obeng, Zhang, Zhang, \& Li, 2016b). The $I_{2}$ receptor ligand-opioid interaction is also determined by the $I_{2}$ receptor ligands used. For example, the $\mathrm{I}_{2}$ receptor ligand phenyzoline produced synergistic antinociceptive interactions with oxycodone in CFA-treated rats (Thorn et al., 2015). CR4056 produced synergistic interactions with morphine in capsaicin-induced neurogenic pain (Ferrari et al., 2011) and postoperative pain (Lanza et al., 2014). Interestingly, when studied in combination with acetaminophen, 2-BFI produced antagonistic to additive interactions while phenyzoline produced additive to synergistic interactions in CFA-treated rats (Siemian, Li, et al., 2016a). However, the same combinations also reduced foodmaintained operant responding in a synergistic manner, suggesting that the antinociceptive interactions are not specific and that the combination may also lead to increased adverse effects (Siemian, Li, et al., 2016a). Together, these results suggest that $I_{2}$ receptor ligands and opioids produce overall preferable antinociceptive interactions under several different painful conditions. The nature of the interactions could be impacted by several factors such as the drugs (both $\mathrm{I}_{2}$ receptor ligands and opioids) used and the pain conditions.

Although many studies have demonstrated beneficial interactions between $\mathrm{I}_{2}$ receptor ligands and opioids for antinociception, concerns remain regarding the adverse effects related to opioid use. Clinical opioid use for pain management and other applications is limited by significant adverse effects of opioids such as constipation, dependence and addiction potential. Thus, simultaneous increase of opioid-related adverse effects by $\mathrm{I}_{2}$ receptor ligands could dampen the potential clinical utility of the $\mathrm{I}_{2}$ receptor ligands-opioids combination therapy for pain management. Two studies examined this concern. In one study, BU224 reduced some observable withdrawal signs in morphine-dependent rats that received naltrexone challenge (Hudson et al., 1999). In a more systematic study, naltrexone treatment disrupted food-maintained operant responding in chronically morphine-treated rats (Thorn, Zhang, \& Li, 2016). 2-BFI treatment reduced the development of tolerance to morphine and attenuated body weight loss after naltrexone treatment (Thorn, Zhang, et al., 2016). All the $\mathrm{I}_{2}$ receptor ligands (2-BFI, BU224 and CR4056) also significantly reduced the development of antinociceptive tolerance in the same study (Thorn, Zhang, et al., 2016). Combined, these results suggest that $I_{2}$ receptor ligands may not simultaneously increase but rather may decrease some adverse effects related to opioid use. These are important supplementary information to supporting the use of $\mathrm{I}_{2}$ receptor ligands alone as monotherapies or combined with opioids as combination therapy strategies for the treatment of pain.

In regard to the combination therapy, it is worth reiterating that because $\mathrm{I}_{2}$ receptor ligands and opioids generally produce additive to synergic antinociceptive interactions, smaller doses are needed to achieve similar analgesia as compared to the individual drugs, which is likely to have less adverse effects such as the development of tolerance and dependence. Indeed, an earlier study found that $\mathrm{I}_{2}$ receptor ligands reduced the antinociceptive tolerance to morphine in an acute nociception assay (radiant heat tail flick) (Boronat, Olmos, \& Garcia-Sevilla, 1998). We recently found that the combination of phenyzoline and oxycodone developed less antinociceptive tolerance and the tolerance developed at a much slower rate as compared to oxycodone alone in both CFA-treated and CCI rats (Thorn, Zhang, \& Li, 2017). 


\subsection{Discriminative stimulus effects}

Drug discrimination is a powerful behavioral procedure for examining the mechanism of action of a novel compound because across many classes, drugs can be distinguished and classified based on their discriminative stimulus effects, and because these classifications often highly correlate with a specific cellular mechanism of action (Schuster \& Johanson, 1988). For example, if a drug with a known mechanism of action is trained as a discriminative stimulus, drugs with the same mechanisms of action typically are able to produce responding on the same operandum as the training drug (i.e., the test drug "substitutes" for the training drug), consistent with their shared mechanism of action. Drug discrimination procedures have been developed in different species (mouse, rat, pigeon, monkey, and human) and most psychotropic drugs can serve as discriminative stimuli.

Several studies have successfully trained rats to discriminate different imidazoline $\mathrm{I}_{2}$ receptor ligands from their vehicle and the discriminative stimulus profiles of these compounds have been described in an effort to understand the related mechanisms of action of the $\mathrm{I}_{2}$ receptor ligands. Rats were trained to discriminate $33 \mu \mathrm{mol} / \mathrm{kg} 2-\mathrm{BFI}(\sim 6 \mathrm{mg} / \mathrm{kg}$, i.p.) from saline (Jordan, Jackson, Nutt, \& Handley, 1996). Substitution studies showed that idazoxan and the $a_{2}$-adrenoceptor antagonist ethoxy idazoxan (RX811059) fully substituted for 2-BFI. Interestingly, the monoamine oxidase inhibitors (MAOIs) moclobemide and pargyline also fully substituted for 2-BFI, suggesting the critical role that MAO inhibition plays in mediating the discriminative stimulus effects of 2-BFI (Jordan et al., 1996). In a following study, the training dose of 2-BFI was $7 \mathrm{mg} / \mathrm{kg}$ (i.p.) and several $\mathrm{I}_{2}$ receptor ligands BU224 and BU226 fully while BU216, LSL60101 and LSL60125 partially substituted for 2BFI (MacInnes \& Handley, 2002). Again, the reversible MAO-A inhibitors moclobemide and RO41-1049, and the beta-carbolines harmane, norharmane and harmaline which also reversibly inhibit MAO-A, all exhibited significant and dose-dependent substitution for 2BFI (MacInnes \& Handley, 2002). Interestingly, the reversible MAO-B inhibitors lazabemide and RO16-1649 failed to substitute for 2-BFI discrimination, which suggests that the discriminative stimulus effects of 2-BFI may be closely related to the inhibition of MAO-A (MacInnes \& Handley, 2002). Because MAO-A plays an essential role in monoamine synthesis and because microdialysis studies show increased extracellular level of monoamines in the brain after $I_{2}$ receptor ligands treatment (Hudson et al., 1999), it is reasonable to predict that the modulation of monoamines may contribute to the discriminative stimulus effects of $I_{2}$ receptor ligands. Indeed, the monoamine-releasing agents amphetamine and fenfluramine dose-dependently substituted for 2-BFI, while norepinephrine (desipramine, reboxetine) and serotonin (clomipramine, citalopram) reuptake inhibitors all partially substituted for 2-BFI (MacInnes \& Handley, 2003). These results suggest that the discriminative stimulus effects of 2-BFI may involve noradrenergic and serotonergic components.

Other $\mathrm{I}_{2}$ receptor ligands were also used as training drugs (Qiu, He, Zhang, \& Li, 2014a; Qiu, Zhang, \& $\mathrm{Li}$, 2015). In rats discriminating $5.6 \mathrm{mg} / \mathrm{kg}$ BU224 (i.p.) from saline, $\mathrm{I}_{2}$ receptor ligands tracizoline, RS45041, CR4056, phenyzoline and idazoxan, as well as the MAO-A inhibitor harmane, all fully substituted for BU224 (Qiu et al., 2015). Similarly, in rats discriminating $32 \mathrm{mg} / \mathrm{kg}$ phenyzoline (i.p.) from saline, full substitution was also seen 
when tracizoline, RS45041, CR4056, phenyzoline and harmane were studied, respectively (Qiu et al., 2015). In rats discriminating $10 \mathrm{mg} / \mathrm{kg}$ CR4056 (i.p.) from its vehicle, phenyzoline, RS45041, tracizoline and idazoxan all fully substituted for CR4056, while 2BFI partially substituted for CR4056 and BU224 failed to produce significant CR4056-like discriminative stimulus effect up to the dose that eliminated operant responding (Qiu et al., 2014a). In this study, harmane failed to produce significant CR4056-like discriminative stimulus effect (Qiu et al., 2014a). Overall, these studies suggest that the purported selective $\mathrm{I}_{2}$ receptor ligands share similar mechanisms of action that presumably are an essential component of $\mathrm{I}_{2}$ receptors. The fact that many of the $\mathrm{I}_{2}$ receptor ligands such as 2-BFI, BU224, phenyzoline and tracizoline all produce symmetrical substitutions when different ligands were used as training drugs and that all have high and selective binding affinities on $\mathrm{I}_{2}$ receptors as defined by receptor binding assays strongly suggest that these compounds recognize a common mechanism ( $\mathrm{I}_{2}$ receptor mediation) and that $\mathrm{I}_{2}$ receptor ligands produce a characteristic interoceptive cue that is different from many other psychoactive drugs such as opioids and ketamine (Qiu et al., 2014a).

One puzzling question in the $\mathrm{I}_{2}$ receptor ligand discrimination studies is that idazoxan fully substitutes for all the studied $\mathrm{I}_{2}$ receptor ligands. This is in contrast to most studies that examine the antinociceptive effects of $\mathrm{I}_{2}$ receptor ligands. In those studies, idazoxan reliably blocks the antinociceptive actions of many $\mathrm{I}_{2}$ receptor ligands (Ferrari et al., 2011; Lanza et al., 2014; Li et al., 2014; J. X. Li et al., 2011) and it is considered the only known $\mathrm{I}_{2}$ receptor antagonist (but see Thorn et al., 2016 for an exception). Thus, the same drug (idazoxan) acts as an agonist in one behavioral endpoint (drug discrimination) but acts as an antagonist in a different behavioral endpoint (antinociception) when interacting with the same $\mathrm{I}_{2}$ receptor ligands (e.g., 2-BFI, CR4056). The only reasonable interpretation to reconcile these discrepancies seems to suggest that there exist more than one " $\mathrm{I}_{2}$ receptor" and that idazoxan has opposing pharmacological effects on them. Considering that $\mathrm{I}_{2}$ receptors have multiple component proteins (Olmos, Alemany, et al., 1999), it seems possible that actions of $I_{2}$ receptor ligands on one component produce one pharmacological effect (e.g., discriminative stimulus effect) while their actions on a different component produce another pharmacological effect (e.g., antinociception), and that idazoxan acts differently on both components. This proposition seems sufficient to explain the apparently discordant in vivo functional results and was discussed previously (Qiu et al., 2014a; Qiu et al., 2015; Thorn, Qiu, et al., 2016). This notion is further supported by two other findings. First, 2-BFI and BU224 produced seizure at larger doses which cannot be attenuated by idazoxan (Min, Peng, He, Zhang, \& Li, 2013). Second, idazoxan cannot attenuate $\mathrm{I}_{2}$ receptor ligandsinduced antinociceptive effects in phase II of the formalin test (Thorn, Qiu, et al., 2016). Combined, it does seem that $\mathrm{I}_{2}$ receptors have at least two different functional components, one is idazoxan-sensitive and another is idazoxan-insensitive (Thorn, Qiu, et al., 2016) (also see section 4. 3 Neuroprotection)

\subsection{Neuroprotection}

Early studies showed that idazoxan decreased neuronal damage in the rat brain in a model of transient global forebrain ischemia (Gustafson, Miyauchi, \& Wieloch, 1989; Gustafson, Westerberg, \& Wieloch, 1990). It was later found that idazoxan produced a small yet 
prolonged ( 3 hours) hypothermia, for which the hypothermia significantly correlated with reduced cell loss and increased gliosis in the hippocampus. Importantly, BU224 had no neuroprotective effect in this model at the doses used ( 3 injections of 0.2 to $1 \mathrm{mg} / \mathrm{kg}$ ) (Craven \& Conway, 1997). It appears that the dose of BU224 used was too small in that study to produce significant body temperature change (Thorn, An, Zhang, Pigini, \& Li, 2012); nevertheless, it was concluded that idazoxan was ineffective in neuroprotection and any effect may be due to the hypothermia induced by the dose of idazoxan examined (Craven \& Conway, 1997). In a rat focal cerebral hypoxia-ischemia model, it was found that idazoxan does not prevent but worsen the brain damage (Antier, Franconi, \& Sannajust, 1999). Unfortunately, because idazoxan binds to multiple receptors ( $a_{2}$ adrenoceptor, imidazoline $I_{1}$ and $I_{2}$ receptors, to name a few), the receptor mechanism underlying the effects reported in the above studies were unknown.

Recently, several studies showed that the selective $\mathrm{I}_{2}$ receptor ligand, 2-BFI, had neuroprotective effect against brain injury induced by middle cerebral artery occlusion, a rat model of transient cerebral ischemia (Han et al., 2012; Han et al., 2009; Han, Zhang, Tian, Zheng, \& Hou, 2010). In an effort to explore the underlying mechanisms that contribute to the neuroprotective actions of 2-BFI, several cellular and molecular mechanisms were proposed. It was found that 2-BFI and idazoxan both produced transient and reversible inhibition of intracellular calcium influx through NMDA receptors (Jiang et al., 2010). 2BFI also inhibits NMDA but not AMPA currents (Han, Yang, Jiang, Hou, \& Zheng, 2013). Interaction of $\mathrm{I}_{2}$ receptor ligands with NMDA receptors was previously reported (Olmos, DeGregorio-Rocasolano, et al., 1999; Olmos, Ribera, \& Garcia-Sevilla, 1996), and these results support that $\mathrm{I}_{2}$ receptor ligands can modulate NMDA receptor activity. These mechanisms are used to interpret the neuroprotective effects of 2-BFI and idazoxan in a glutamate toxicity test using cortical neurons in vitro (Han et al., 2013; Jiang et al., 2010). In the same cerebral ischemia model, it was found that 2-BFI reduced TUNEL positive cells, preserved the integrity of subcellular structures, and significantly increased the expression level of Bcl-2, further confirming neuroprotection at the cellular and molecular levels (Han et al., 2010). To further extend the molecular observations from 2-BFI to other $I_{2}$ receptor ligands, a recent study examined the effects of acute and chronic treatment with four different $\mathrm{I}_{2}$ receptor ligands (2-BFI, tracizoline, BU224 and LSL60101) on a battery of molecules on canonical apoptotic pathways (Garau, Miralles, \& Garcia-Sevilla, 2013). A summary of the results can be seen in Table 2 . In short, there lacks any consistency among the four compounds in their effects on all the apoptotic biomarkers. It is difficult to explain the results, although a general conclusion was made that $\mathrm{I}_{2}$ receptor ligands reduced apoptotic signaling (e.g., Bax and cytochrome c) and/or up-regulated survival anti-apoptotic factors (e.g., p-Ser194 FADD/FADD ratio, Bcl-2/Bax ratio) (Garau et al., 2013). Similarly, another study showed disparate biochemical and behavioral changes in a mouse seizure model, and the lack of correlation between the biochemical and behavioral results is difficult to reconcile (Keller \& Garcia-Sevilla, 2016).

While effects of $I_{2}$ receptor ligands on the biochemical factors may be useful to interpret the neuroprotective effects of certain $\mathrm{I}_{2}$ receptor ligands, 2-BFI was the only selective $\mathrm{I}_{2}$ receptor ligand that was ever tested in in vivo functional studies that involve a wellcharacterized animal model and generalization has not been attempted to other $\mathrm{I}_{2}$ receptor 
ligands. This is problematic because with the marked inconsistencies on the effects of the $\mathrm{I}_{2}$ receptor ligands on biochemical markers, it is impossible to link any of those changes to a specific $\mathrm{I}_{2}$ receptor component. In addition, the effects are also only correlational, and it is unknown whether the molecules are actually on the $\mathrm{I}_{2}$ receptor signaling pathway. The above biomarker changes induced by $\mathrm{I}_{2}$ receptor ligands were also certainly inconsistent with findings from in vivo studies in pain and drug discrimination. For example, while LSL60101 did not lead to significant changes on any of the biomarkers, it enhanced morphine antinociception, similar to 2-BFI, and substituted for 2-BFI in 2-BFI discrimination rats (MacInnes \& Handley, 2002; Sanchez-Blazquez et al., 2000). Moreover, while tracizoline showed different pattern in changing these biomarkers from that induced by 2-BFI, the two compounds showed strikingly similar behavioral effects: they both produced anti-hyperalgesia, reduced body temperature and demonstrated symmetrical substitution in drug discrimination (Li et al., 2014; Qiu et al., 2015; Thorn et al., 2012). It would be interesting to see whether tracizoline is effective in animal models of ischemia or stroke as that would represent an important generalization from 2-BFI and would also provide supporting information on whether the biochemical changes are related to neuroprotection. Together, the existing evidence suggests that although the $\mathrm{I}_{2}$ receptor ligand-induced biochemical changes may be related to neuroprotection, they have little relevance to other behavioral actions such as analgesia and discriminative stimulus effects.

\subsection{Body temperature}

Imidazoline $\mathrm{I}_{2}$ receptor ligands are shown to reduce body temperature, an effect that is specifically mediated by $I_{2}$ receptors (Thorn et al., 2012). Indeed, all tested $I_{2}$ receptor ligands produced dose- and time-dependent hypothermia in rats. The hypothermic effect was nearly fully reversed by a pretreatment with idazoxan, but not by the imidazoline $\mathrm{I}_{1}$ receptor antagonist efaroxan or the $a_{2}$-adrenoceptor antagonist yohimbine, suggesting that $I_{2}$ receptors primarily mediate the observed hypothermia (Thorn et al., 2012). Given the relatively simple and quick nature of hypothermia measurement, this measure, together with antagonism tests, could serve as a preliminary in vivo bioassay to develop and discover novel $\mathrm{I}_{2}$ receptor ligands (Abas et al., 2017). In addition, because hypothermia is well known to have beneficial effect in cerebral ischemia and can cause significant neuroprotection even with a small body temperature drop (Craven \& Conway, 1997), $\mathrm{I}_{2}$ receptor ligands-induced hypothermia may partially contribute to their neuroprotective activity (Craven \& Conway, 1997).

\section{Summary and future perspectives}

Since the concept of imidazoline $I_{2}$ receptors was first introduced more than two decades ago, our understanding of this receptor has been seeing a steady increase. $\mathrm{I}_{2}$ receptors represent a group of binding sites that may include several different components. However, the nature of these components and their biological significance remain unclear. With the increased use of advanced technologies such as proteomics, it is reasonable to predict that the several proteins that $I_{2}$ receptor ligands recognize will be deciphered in the near future. This, of course, relies on new researchers who have related research expertise and who are interested in this particular question. 
Despite the elusive nature of $\mathrm{I}_{2}$ receptors, recent years have seen exciting possibilities that $\mathrm{I}_{2}$ receptor ligands could have important clinical applications in several neurological disorders such as pain and neuroprotection. In particular, a large body of literature now consistently demonstrates that $\mathrm{I}_{2}$ receptor ligands are efficacious in various animal models of chronic pain. One compound, CR4056, has even advanced to phase II clinical trial. If approved, this will represent the most important achievement in imidazoline receptor research. Regardless, there is little doubt now that $\mathrm{I}_{2}$ receptors represent a novel and viable drug target for the development of new analgesics for the management of chronic pain. Accumulating data also begin to reveal that different pharmacological effects of the $\mathrm{I}_{2}$ receptor ligands are mediated by different components of $I_{2}$ receptors. It is conceivable that after the molecular identities of the $\mathrm{I}_{2}$ receptor-related proteins are confirmed, the biological functions of certain $\mathrm{I}_{2}$ receptor components can be translated to component-specific $\mathrm{I}_{2}$ receptor ligands which may possess desirable therapeutic actions (e.g., analgesia) without adverse effects related to other $I_{2}$ receptor components. This should be the long-term goal in the field of $I_{2}$ receptor pharmacology research.

An alternative approach to facilitate our understanding of $I_{2}$ receptors is to take advantage of the known $\mathrm{I}_{2}$ receptor ligand-induced pharmacological effects to understand the related mechanisms. For example, it is known that many $\mathrm{I}_{2}$ receptor ligands produce idazoxansensitive antinociceptive effects; however, nothing is known about the mechanisms: how $\mathrm{I}_{2}$ receptor ligand operates at a specific $\mathrm{I}_{2}$ receptor-related protein (component), and how that signal eventually transduces to the pain signaling pathway and produces analgesia. Because $\mathrm{I}_{2}$ receptor ligands functionally inhibit monoamine oxidase and subsequently increase the monoamine levels (Hudson et al., 1999), the increased monoamines may activate specific monoamine receptors, which lead to certain behavioral effects such as analgesia. Therefore, the understanding of such mechanisms as the involvement of monoaminergic system and specific monoamine receptors in the descending inhibitory pathway of pain processing will be important (Bannister, Bee, \& Dickenson, 2009; Bannister \& Dickenson, 2016; Bee \& Dickenson, 2009). Moreover, neuroinflammation plays a major role in initiating and maintaining chronic pain (Ji, Chamessian, \& Zhang, 2016). Because drugs that modulate monoamine system such as amitriptyline have analgesic activity and modulate central neuroinflammation (Zychowska, Rojewska, Makuch, Przewlocka, \& Mika, 2015), $\mathrm{I}_{2}$ receptor ligands may produce antinociceptive actions through the modulation of chronic pain-induced neuroinflammation. Fully addressing these questions will substantially increase our understanding of $\mathrm{I}_{2}$ receptor pharmacology and facilitating the discovery of $\mathrm{I}_{2}$ receptor-based pharmacotherapies to treat pain and other conditions.

\section{Acknowledgments}

This work was supported in part by the National Institute on Drug Abuse, National Institute s of Health, USA (DA034806 and DA033426) and the National Natural Science Foundation of China (81373390). The content is solely the responsibility of the author and does not necessarily represent the official views of the National Institutes of Health.

\section{Abbreviations}

\section{2-BFI 2-(2-benzofuranyl)-2-imidazoline}


AMPA a-amino-3-hydroxy-5-methyl-4-isoxazolepropionic acid

Bcl-2 B-cell lymphoma 2

BU216 3-[4,5-dihydroimidaz-2-yl]-quinoline hydrochloride

BU224 2-(4, 5-dihydroimidazol-2-yl) quinolone

BU226 2-[4,5-dihydroimidaz-2-yl]-isoquinoline hydrochloride

CCI chronic constriction injury

CFA complete Freund's adjuvant

CNS central nervous system

CR4056 2-phenyl-6-(1H imidazol-1yl) quinazoline

FADD Fas-associated protein with death domain

LSL60101 2-(2-benzofuranyl)imidazole

kD kilodalton

LSL 60125 2-(6-methoxybenzofuran 2-yl)imidazole

MAO monoamine oxidase

NAQ 17-cyclopropylmethyl-3,14ß-dihydroxy-4,5a-epoxy-6a-[(3' isoquinolyl)acetamido]morphinan

NMDA $\quad N$-methyl-D-aspartate

RO16-1649 N-(2-aminoethyl)-4-chlorobenzamide hydrochloride

RO41-1049 N-(2-aminoethyl)-5-(3-fluorophenyl)-4-thiazolecarboxamide hydrochloride

RS45041 4-Chloro-2-(imidazolin-2-yl) isoindoline

S22687 5-[2-methyl phenoxy methyl] 1, 3-oxazolin-2-yl) amine

TUNEL terminal deoxynucleotidyl transferase dUTP nick end labeling

\section{References}

Abas S, Erdozain AM, Keller B, Rodriguez-Arevalo S, Callado LF, Garcia-Sevilla JA, Escolano C. Neuroprotective Effects of a Structurally New Family of High Affinity Imidazoline I2 Receptor Ligands. ACS Chem Neurosci. 2017; doi: 10.1021/acschemneuro.6b00426

Alexander SP, Mathie A, Peters JA. Guide to Receptors and Channels (GRAC). Br J Pharmacol (5th). 2011; 164(Suppl 1):S1-324. DOI: 10.1111/j.1476-5381.2011.01649_1.x [PubMed: 22040146]

Anderson NJ, Seif I, Nutt DJ, Hudson AL, Robinson ES. Autoradiographical distribution of imidazoline binding sites in monoamine oxidase A deficient mice. J Neurochem. 2006; 96(6):15511559. DOI: 10.1111/j.1471-4159.2006.03662.x [PubMed: 16476082]

Antier D, Franconi F, Sannajust F. Idazoxan does not prevent but worsens focal hypoxic-ischemic brain damage in neonatal Wistar rats. J Neurosci Res. 1999; 58(5):690-696. [PubMed: 10561697] 
Bannister K, Bee LA, Dickenson AH. Preclinical and early clinical investigations related to monoaminergic pain modulation. Neurotherapeutics. 2009; 6(4):703-712. DOI: 10.1016/j.nurt. 2009.07.009 [PubMed: 19789074]

Bannister K, Dickenson AH. What do monoamines do in pain modulation? Curr Opin Support Palliat Care. 2016; 10(2):143-148. DOI: 10.1097/SPC.0000000000000207 [PubMed: 27043287]

Bee LA, Dickenson AH. The importance of the descending monoamine system for the pain experience and its treatment. F1000 Med Rep. 2009; 1doi: 10.3410/M1-83

Boronat MA, Olmos G, Garcia-Sevilla JA. Attenuation of tolerance to opioid-induced antinociception and protection against morphine-induced decrease of neurofilament proteins by idazoxan and other I2-imidazoline ligands. Br J Pharmacol. 1998; 125(1):175-185. DOI: 10.1038/sj.bjp.0702031 [PubMed: 9776358]

Brunton, L., Chabner, B., Knollman, B. Goodman and Gilman's the Pharmacological Basis of Therapeutics. New York: McGraw-Hill Education; 2011.

Coupry I, Podevin RA, Dausse JP, Parini A. Evidence for imidazoline binding sites in basolateral membranes from rabbit kidney. Biochem Biophys Res Commun. 1987; 147(3):1055-1060. [PubMed: 2889454]

Craven JA, Conway EL. Effects of alpha 2-adrenoceptor antagonists and imidazoline2-receptor ligands on neuronal damage in global ischaemia in the rat. Clin Exp Pharmacol Physiol. 1997; 24(2):204207. [PubMed: 9075597]

Diamant S, Eldar-Geva T, Atlas D. Imidazoline binding sites in human placenta: evidence for heterogeneity and a search for physiological function. Br J Pharmacol. 1992; 106(1):101-108. [PubMed: 1324063]

Eglen RM, Hudson AL, Kendall DA, Nutt DJ, Morgan NG, Wilson VG, Dillon MP. 'Seeing through a glass darkly': casting light on imidazoline 'I' sites. Trends Pharmacol Sci. 1998; 19(9):381-390. [PubMed: 9786027]

Ernsberger P, Meeley MP, Mann JJ, Reis DJ. Clonidine binds to imidazole binding sites as well as alpha 2-adrenoceptors in the ventrolateral medulla. Eur J Pharmacol. 1987; 134(1):1-13. [PubMed: 3030779]

Ferrari F, Fiorentino S, Mennuni L, Garofalo P, Letari O, Mandelli S, Caselli G. Analgesic efficacy of CR4056, a novel imidazoline-2 receptor ligand, in rat models of inflammatory and neuropathic pain. J Pain Res. 2011; 4:111-125. DOI: 10.2147/JPR.S18353 [PubMed: 21647215]

Garau C, Miralles A, Garcia-Sevilla JA. Chronic treatment with selective I2-imidazoline receptor ligands decreases the content of pro-apoptotic markers in rat brain. J Psychopharmacol. 2013; 27(2):123-134. DOI: 10.1177/0269881112450785 [PubMed: 22719017]

Gentili F, Cardinaletti C, Carrieri A, Ghelfi F, Mattioli L, Perfumi M, Pigini M. Involvement of I2imidazoline binding sites in positive and negative morphine analgesia modulatory effects. Eur J Pharmacol. 2006; 553(1-3):73-81. DOI: 10.1016/j.ejphar.2006.09.031 [PubMed: 17081513]

Gustafson I, Miyauchi Y, Wieloch TW. Postischemic administration of idazoxan, an alpha-2 adrenergic receptor antagonist, decreases neuronal damage in the rat brain. J Cereb Blood Flow Metab. 1989; 9(2):171-174. DOI: 10.1038/jcbfm.1989.25 [PubMed: 2564004]

Gustafson I, Westerberg E, Wieloch T. Protection against ischemia-induced neuronal damage by the alpha 2-adrenoceptor antagonist idazoxan: influence of time of administration and possible mechanisms of action. J Cereb Blood Flow Metab. 1990; 10(6):885-894. DOI: 10.1038/jcbfm. 1990.145 [PubMed: 1976642]

Han Z, Cheng ZH, Liu S, Yang JL, Xiao MJ, Zheng RY, Hou ST. Neurovascular protection conferred by 2-BFI treatment during rat cerebral ischemia. Biochem Biophys Res Commun. 2012; 424(3): 544-548. DOI: 10.1016/j.bbrc.2012.06.152 [PubMed: 22771326]

Han Z, Xiao MJ, Shao B, Zheng RY, Yang GY, Jin K. Attenuation of ischemia-induced rat brain injury by 2-(-2-benzofuranyl)-2-imidazoline, a high selectivity ligand for imidazoline I(2) receptors. Neurol Res. 2009; 31(4):390-395. DOI: 10.1179/174313209X444116 [PubMed: 19508825]

Han Z, Yang JL, Jiang SX, Hou ST, Zheng RY. Fast, non-competitive and reversible inhibition of NMDA-activated currents by 2-BFI confers neuroprotection. PLoS One. 2013; 8(5):e64894.doi: 10.1371/journal.pone.0064894 [PubMed: 23741413] 
Han Z, Zhang HX, Tian JS, Zheng RY, Hou ST. 2-(-2-benzofuranyl)-2-imidazoline induces Bcl-2 expression and provides neuroprotection against transient cerebral ischemia in rats. Brain Res. 2010; 1361:86-92. DOI: 10.1016/j.brainres.2010.09.029 [PubMed: 20840843]

Head GA, Mayorov DN. Imidazoline receptors, novel agents and therapeutic potential. Cardiovasc Hematol Agents Med Chem. 2006; 4(1):17-32. [PubMed: 16529547]

Hudson AL, Gough R, Tyacke R, Lione L, Lalies M, Lewis J, Nutt DJ. Novel selective compounds for the investigation of imidazoline receptors. Ann N Y Acad Sci. 1999; 881:81-91. [PubMed: 10415900]

Hunskaar S, Hole K. The formalin test in mice: dissociation between inflammatory and noninflammatory pain. Pain. 1987; 30(1):103-114. [PubMed: 3614974]

Ji RR, Chamessian A, Zhang YQ. Pain regulation by non-neuronal cells and inflammation. Science. 2016; 354(6312):572-577. DOI: 10.1126/science.aaf8924 [PubMed: 27811267]

Jiang SX, Zheng RY, Zeng JQ, Li XL, Han Z, Hou ST. Reversible inhibition of intracellular calcium influx through NMDA receptors by imidazoline I(2) receptor antagonists. Eur J Pharmacol. 2010; 629(1-3):12-19. DOI: 10.1016/j.ejphar.2009.11.063 [PubMed: 19958763]

Jordan S, Jackson HC, Nutt DJ, Handley SL. Discriminative stimulus produced by the imidazoline I2 site ligand, 2 -BFI. J Psychopharmacol. 1996; 10(4):273-278. DOI: 10.1177/026988119601000403 [PubMed: 22302973]

Keller B, Garcia-Sevilla JA. Immunodetection and subcellular distribution of imidazoline receptor proteins with three antibodies in mouse and human brains: Effects of treatments with I1- and I2imidazoline drugs. J Psychopharmacol. 2015; 29(9):996-1012. DOI: 10.1177/0269881115586936 [PubMed: 26038110]

Keller B, Garcia-Sevilla JA. Inhibitory effects of imidazoline receptor ligands on basal and kainic acidinduced neurotoxic signalling in mice. J Psychopharmacol. 2016; 30(9):875-886. [PubMed: 27302941]

Kimura A, Tyacke RJ, Robinson JJ, Husbands SM, Minchin MC, Nutt DJ, Hudson AL. Identification of an imidazoline binding protein: creatine kinase and an imidazoline-2 binding site. Brain Res. 2009; 1279:21-28. DOI: 10.1016/j.brainres.2009.04.044 [PubMed: 19410564]

Lanza M, Ferrari F, Menghetti I, Tremolada D, Caselli G. Modulation of imidazoline I2 binding sites by CR4056 relieves postoperative hyperalgesia in male and female rats. Br J Pharmacol. 2014; 171(15):3693-3701. DOI: 10.1111/bph.12728 [PubMed: 24758515]

Li, Thorn DA, Qiu Y, Peng BW, Zhang Y. Antihyperalgesic effects of imidazoline I(2) receptor ligands in rat models of inflammatory and neuropathic pain. Br J Pharmacol. 2014; 171(6):1580-1590. DOI: 10.1111/bph.12555 [PubMed: 24329196]

Li G, Regunathan S, Barrow CJ, Eshraghi J, Cooper R, Reis DJ. Agmatine: an endogenous clonidinedisplacing substance in the brain. Science. 1994; 263(5149):966-969. [PubMed: 7906055]

Li JX, Zhang Y. Imidazoline I2 receptors: target for new analgesics? Eur J Pharmacol. 2011; 658(2-3): 49-56. DOI: 10.1016/j.ejphar.2011.02.038 [PubMed: 21371460]

Li JX, Zhang Y, Winter JC. Morphine-induced antinociception in the rat: supra-additive interactions with imidazoline I(2) receptor ligands. Eur J Pharmacol. 2011; 669(1-3):59-65. DOI: 10.1016/ j.ejphar.2011.07.041 [PubMed: 21867697]

MacInnes N, Handley SL. Characterization of the discriminable stimulus produced by 2-BFI: effects of imidazoline I(2)-site ligands, MAOIs, beta-carbolines, agmatine and ibogaine. Br J Pharmacol. 2002; 135(5):1227-1234. DOI: 10.1038/sj.bjp.0704579 [PubMed: 11877331]

MacInnes N, Handley SL. Potential serotonergic and noradrenergic involvement in the discriminative stimulus effects of the selective imidazoline I2-site ligand 2-BFI. Pharmacol Biochem Behav. 2003; 75(2):427-433. [PubMed: 12873635]

Meregalli C, Ceresa C, Canta A, Carozzi VA, Chiorazzi A, Sala B, Cavaletti G. CR4056, a new analgesic I2 ligand, is highly effective against bortezomib-induced painful neuropathy in rats. $\mathrm{J}$ Pain Res. 2012; 5:151-167. DOI: 10.2147/JPR.S32122 [PubMed: 22792002]

Michel MC, Ernsberger P. Keeping an eye on the I site: imidazoline-preferring receptors. Trends Pharmacol Sci. 1992; 13(10):369-370. [PubMed: 1413085] 
Min JW, Peng BW, He X, Zhang Y, Li JX. Gender difference in epileptogenic effects of 2-BFI and BU224 in mice. Eur J Pharmacol. 2013; 718(1-3):81-86. DOI: 10.1016/j.ejphar.2013.09.016 [PubMed: 24055191]

Miralles A, Olmos G, Sastre M, Barturen F, Martin I, Garcia-Sevilla JA. Discrimination and pharmacological characterization of I2-imidazoline sites with [3H]idazoxan and alpha-2 adrenoceptors with $[3 \mathrm{H}] \mathrm{RX} 821002$ (2-methoxy idazoxan) in the human and rat brains. J Pharmacol Exp Ther. 1993; 264(3):1187-1197. [PubMed: 8095548]

Nielsen AN, Mathiesen C, Blackburn-Munro G. Pharmacological characterisation of acid-induced muscle allodynia in rats. Eur J Pharmacol. 2004; 487(1-3):93-103. DOI: 10.1016/j.ejphar. 2004.01.017 [PubMed: 15033380]

Olmos G, Alemany R, Boronat MA, Garcia-Sevilla JA. Pharmacologic and molecular discrimination of I2-imidazoline receptor subtypes. Ann N Y Acad Sci. 1999; 881:144-160. [PubMed: 10415910]

Olmos G, DeGregorio-Rocasolano N, Paz Regalado M, Gasull T, Assumpcio Boronat M, Trullas R, Garcia-Sevilla JA. Protection by imidazol(ine) drugs and agmatine of glutamate-induced neurotoxicity in cultured cerebellar granule cells through blockade of NMDA receptor. Br J Pharmacol. 1999; 127(6):1317-1326. DOI: 10.1038/sj.bjp.0702679 [PubMed: 10455281]

Olmos G, Ribera J, Garcia-Sevilla JA. Imidazoli(di)ne compounds interact with the phencyclidine site of NMDA receptors in the rat brain. Eur J Pharmacol. 1996; 310(2-3):273-276. [PubMed: 8884227]

Parini A, Moudanos CG, Pizzinat N, Lanier SM. The elusive family of imidazoline binding sites. Trends Pharmacol Sci. 1996; 17(1):13-16. [PubMed: 8789353]

Piletz JE, Aricioglu F, Cheng JT, Fairbanks CA, Gilad VH, Haenisch B, Gilad GM. Agmatine: clinical applications after 100 years in translation. Drug Discov Today. 2013; 18(17-18):880-893. DOI: 10.1016/j.drudis.2013.05.017 [PubMed: 23769988]

Qiu Y, He XH, Zhang Y, Li JX. Discriminative stimulus effects of the novel imidazoline I(2) receptor ligand CR4056 in rats. Sci Rep. 2014a; 4:6605.doi: 10.1038/srep06605 [PubMed: 25308382]

Qiu Y, Thorn DA, Zhang Y, He X, Li JX. Behavioral effects of the imidazoline I2 receptor ligand BU99006 in rats. Behav Pharmacol. 2014b; 25(2):130-136. [PubMed: 24518265]

Qiu Y, Zhang Y, Li JX. Discriminative stimulus effects of the imidazoline I2 receptor ligands BU224 and phenyzoline in rats. Eur J Pharmacol. 2015; 749:133-141. DOI: 10.1016/j.ejphar.2015.01.013 [PubMed: 25617792]

Regunathan S, Reis DJ. Imidazoline receptors and their endogenous ligands. Annu Rev Pharmacol Toxicol. 1996; 36:511-544. DOI: 10.1146/annurev.pa.36.040196.002455 [PubMed: 8725400]

Reis DJ, Regunathan S. Is agmatine a novel neurotransmitter in brain? Trends Pharmacol Sci. 2000; 21(5):187-193. [PubMed: 10785653]

Remaury A, Raddatz R, Ordener C, Savic S, Shih JC, Chen K, Parini A. Analysis of the pharmacological and molecular heterogeneity of $\mathrm{I}(2)$-imidazoline-binding proteins using monoamine oxidase-deficient mouse models. Mol Pharmacol. 2000; 58(5):1085-1090. [PubMed: 11040057]

Sampson C, Zhang Y, Del Bello F, Li JX. Effects of imidazoline I2 receptor ligands on acute nociception in rats. Neuroreport. 2012; 23(2):73-77. DOI: 10.1097/WNR.0b013e32834e7db3 [PubMed: 22107843]

Sanchez-Blazquez P, Boronat MA, Olmos G, Garcia-Sevilla JA, Garzon J. Activation of I(2)imidazoline receptors enhances supraspinal morphine analgesia in mice: a model to detect agonist and antagonist activities at these receptors. Br J Pharmacol. 2000; 130(1):146-152. DOI: 10.1038/ sj.bjp.0703294 [PubMed: 10781010]

Schuster CR, Johanson CE. Relationship between the discriminative stimulus properties and subjective effects of drugs. Psychopharmacol Ser. 1988; 4:161-175. [PubMed: 3293041]

Siemian JN, Li J, Zhang Y, Li JX. Interactions between imidazoline I2 receptor ligands and acetaminophen in adult male rats: antinociception and schedule-controlled responding. Psychopharmacology (Berl). 2016a; 233(5):873-882. DOI: 10.1007/s00213-015-4166-9 [PubMed: 26613734] 
Siemian JN, Obeng S, Zhang Y, Zhang Y, Li JX. Antinociceptive Interactions between the Imidazoline I2 Receptor Agonist 2-BFI and Opioids in Rats: Role of Efficacy at the mu-Opioid Receptor. J Pharmacol Exp Ther. 2016b; 357(3):509-519. DOI: 10.1124/jpet.116.232421 [PubMed: 27056847]

Tabor CW, Tabor H. Polyamines. Annu Rev Biochem. 1984; 53:749-790. DOI: 10.1146/annurev.bi. 53.070184.003533 [PubMed: 6206782]

Tesson F, Limon-Boulez I, Urban P, Puype M, Vandekerckhove J, Coupry I, Parini A. Localization of I2-imidazoline binding sites on monoamine oxidases. J Biol Chem. 1995; 270(17):9856-9861. [PubMed: 7730367]

Tesson F, Prip-Buus C, Lemoine A, Pegorier JP, Parini A. Subcellular distribution of imidazolineguanidinium-receptive sites in human and rabbit liver. Major localization to the mitochondrial outer membrane. J Biol Chem. 1991; 266(1):155-160. [PubMed: 1845963]

Thorn DA, An XF, Zhang Y, Pigini M, Li JX. Characterization of the hypothermic effects of imidazoline I(2) receptor agonists in rats. Br J Pharmacol. 2012; 166(6):1936-1945. DOI: 10.1111/j.1476-5381.2012.01894.x [PubMed: 22324428]

Thorn DA, Qiu Y, Jia S, Zhang Y, Li JX. Antinociceptive effects of imidazoline I2 receptor agonists in the formalin test in rats. Behav Pharmacol. 2016; 27(4):377-383. DOI: 10.1097/FBP. 0000000000000206 [PubMed: 26599907]

Thorn DA, Siemian JN, Zhang Y, Li JX. Anti-hyperalgesic effects of imidazoline I2 receptor ligands in a rat model of inflammatory pain: interactions with oxycodone. Psychopharmacology (Berl). 2015; 232(18):3309-3318. DOI: 10.1007/s00213-015-3983-1 [PubMed: 26037946]

Thorn DA, Zhang Y, Li JX. Effects of the imidazoline I2 receptor agonist 2-BFI on the development of tolerance to and behavioural/physical dependence on morphine in rats. Br J Pharmacol. 2016; 173(8):1363-1372. DOI: 10.1111/bph.13435 [PubMed: 26776953]

Thorn DA, Zhang Y, Li JX. Tolerance and cross-tolerance to the antinociceptive effects of oxycodone and the imidazoline $\mathrm{I} 2$ receptor agonist phenyzoline in adult male rats. Psychopharmacology (Berl). 2017 In Press.

Thorn DA, Zhang Y, Peng BW, Winter JC, Li JX. Effects of imidazoline I(2) receptor ligands on morphine- and tramadol-induced antinociception in rats. Eur J Pharmacol. 2011; 670(2-3):435440. DOI: 10.1016/j.ejphar.2011.09.173 [PubMed: 21970802]

Tyacke RJ, Robinson ES, Nutt DJ, Hudson AL. 5-Isothiocyanato-2-benzofuranyl-2-imidazoline (BU99006) an irreversible imidazoline(2) binding site ligand: in vitro and in vivo characterisation in rat brain. Neuropharmacology. 2002; 43(1):75-83. [PubMed: 12213261]

Zychowska M, Rojewska E, Makuch W, Przewlocka B, Mika J. The influence of microglia activation on the efficacy of amitriptyline, doxepin, milnacipran, venlafaxine and fluoxetine in a rat model of neuropathic pain. Eur J Pharmacol. 2015; 749:115-123. DOI: 10.1016/j.ejphar.2014.11.022 [PubMed: 25460025] 

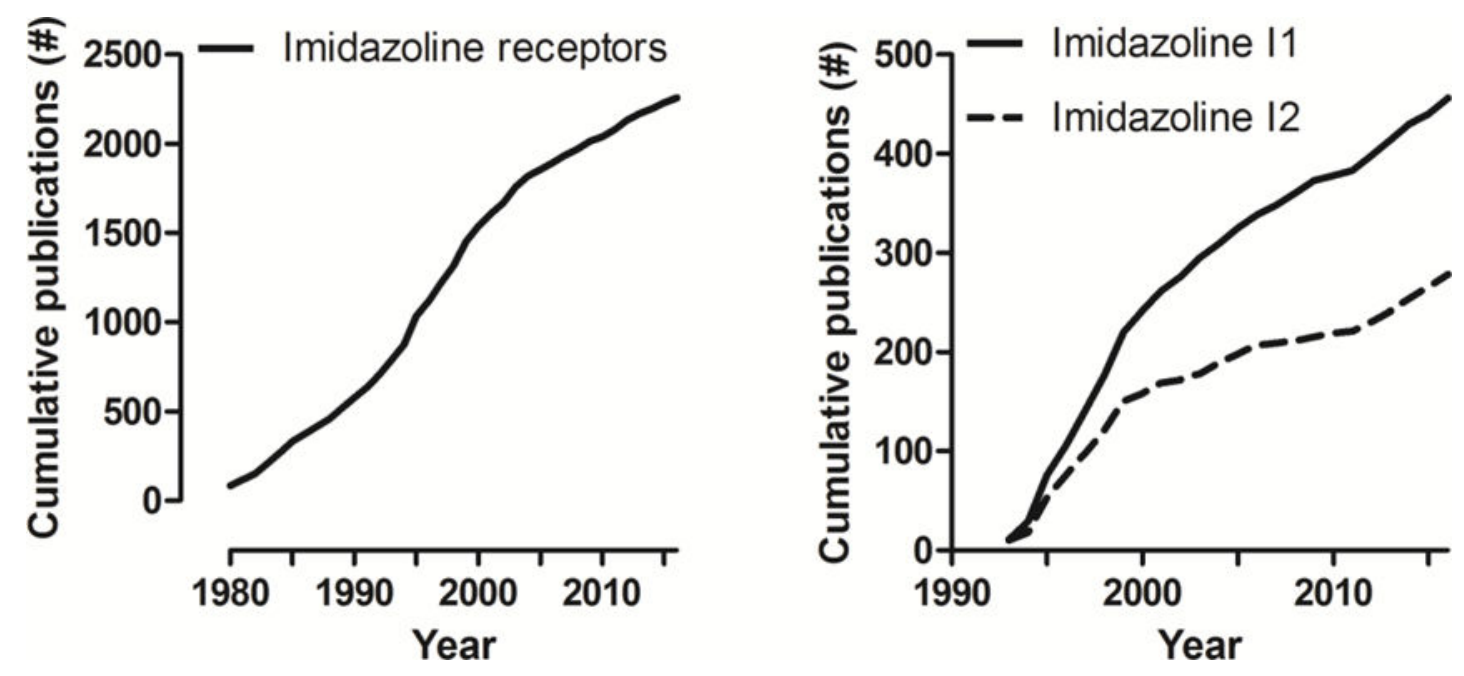

Figure 1.

Left: cumulative publications in PubMed using search term "imidazoline receptors OR imidazoline binding sites"; right: cumulative publications in PubMed using search terms “imidazoline $\mathrm{I}_{1}$ receptors $\mathrm{OR}$ imidazoline $\mathrm{I}_{1}$ binding sites $\mathrm{OR} \mathrm{I}_{1}$-imidazoline" and “imidazoline $\mathrm{I}_{2}$ receptors $\mathrm{OR}$ imidazoline $\mathrm{I}_{2}$ binding sites $\mathrm{OR} \mathrm{I}_{2}$-imidazoline”, respectively. 
Table 1

List of meetings and symposia related to imidazoline receptors.

\begin{tabular}{|c|c|c|c|}
\hline Date & Place & Name & Publications \\
\hline June $29-30,1992$ & Paris, France & $\begin{array}{l}\text { First International Symposium on Imidazoline } \\
\text { Preferring Receptors (a satellite symposium of the } \\
\text { 7th International Catecholamine Symposium, } \\
\text { Amsterdam, Netherland) }\end{array}$ & $\begin{array}{l}\text { Fundamental \& Clinical Pharmacology, } \\
\text { Vol 6/S1, } 1992 \text { (supplement issue) }\end{array}$ \\
\hline July 19-20, 1994 & New York, USA & $\begin{array}{l}\text { Second International Symposium on Imidazoline } \\
\text { Receptors (a satellite meeting of XIIth International } \\
\text { Congress of Pharmacology, Montreal, Canada, } \\
\text { 1994) }\end{array}$ & $\begin{array}{l}\text { The imidazoline receptor: pharmacology, } \\
\text { functions, ligands, and relevance to } \\
\text { biology and medicine (monograph) }\end{array}$ \\
\hline September, 1997 & Melbourne, Australia & $\begin{array}{l}\text { International symposium on imidazoline receptors } \\
\text { (a satellite meeting of the inaugural meeting of the } \\
\text { International Society of Autonomic Neurosciences, } \\
\text { Cairns, Australia) }\end{array}$ & $\begin{array}{l}\text { Journal of the Autonomic Nervous } \\
\text { System, Vol 72/Issue 2-3 (special issue) }\end{array}$ \\
\hline June $22-24,1998$ & Bonn, Germany & $\begin{array}{l}\text { Third International Symposium on Imidazoline } \\
\text { Receptors (a satellite meeting of XIIIth International } \\
\text { Congress of Pharmacology, Munich, Germany, } \\
\text { 1998) }\end{array}$ & $\begin{array}{l}\text { Imidazoline receptors and their } \\
\text { endogenous ligands: current concepts and } \\
\text { therapeutic potential (monograph) }\end{array}$ \\
\hline April 9-11, 2003 & San Diego, USA & $\begin{array}{l}\text { IV International Symposium on Agmatine and } \\
\text { Imidazoline Systems }\end{array}$ & $\begin{array}{l}\text { Agmatine and imidazolines: their novel } \\
\text { receptors and enzymes (monograph) }\end{array}$ \\
\hline
\end{tabular}




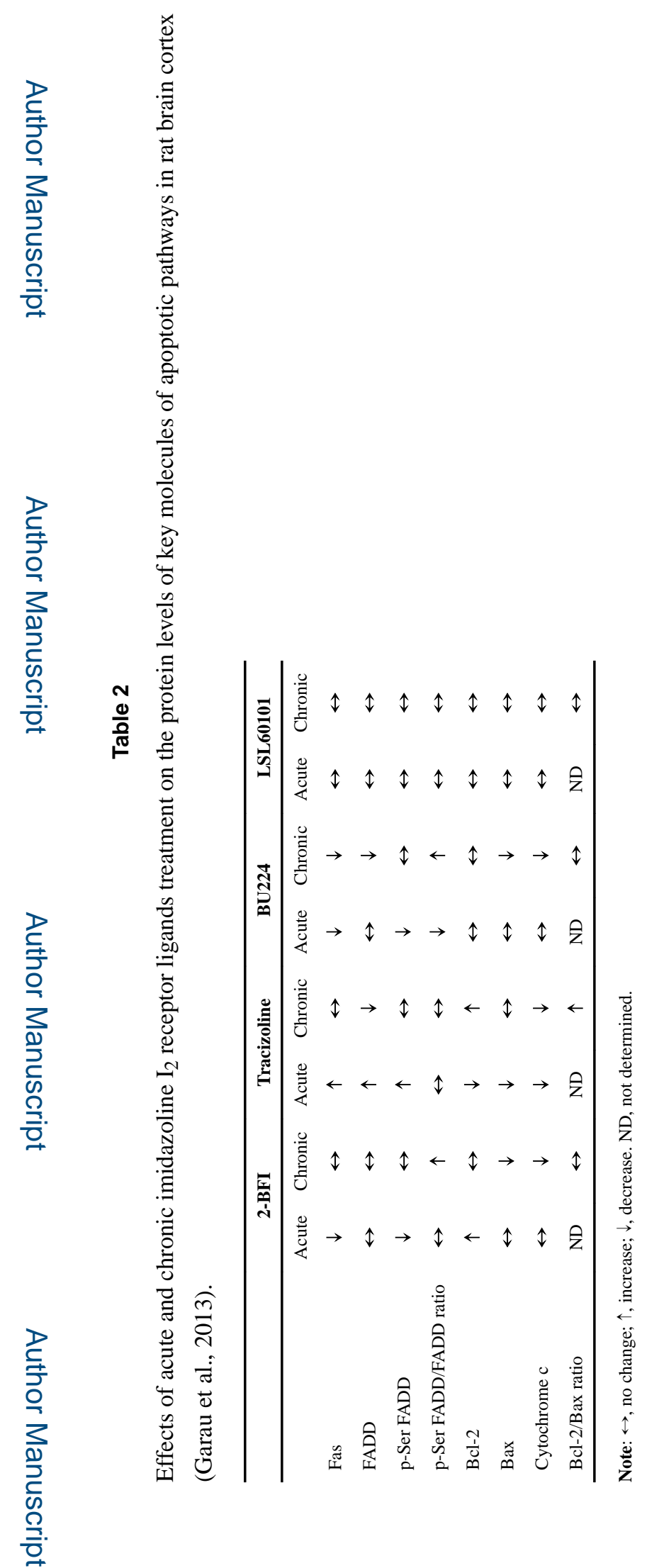

Pharmacol Ther: Author manuscript; available in PMC 2018 October 01. 